\title{
El muadhorib
}

Jurnal Kajian Ekonomi dan Perbankan Syariah

Volume 2 Nomor 1 Juni 2021

E-ISSN: $2722-5615$

http:/ / e-journal.iainfmpapua.ac.id/index.php/elmudhorib

\section{HADIS TENTANG JUAL BELI DAN RIBA: IMPLEMENTASI PADA SISTEM KREDIT}

\author{
Mhd. Rasidin \\ Institut Agama Islam Negeri Kerinci \\ mhd rasidin@yahoo.co.id
}

\author{
Arzam \\ Institut Agama Islam Negeri Kerinci \\ arzam@iainkerinci.ac.id

\section{Zufriani} \\ Institut Agama Islam Negeri Kerinci \\ zufrianistainkerinci@gmail.com

\section{Doli Witro} \\ UIN Sunan Gunung Djati Bandung \\ doliwitro01@gmail.com
}

Received:

January 20, 2021

1st Revision:

July 12, 2021

Published:

July 24, 2021

\begin{abstract}
This paper discusses the buying and selling of credit, which has the potential to contain usury. The sale and purchase of credit are examined from the hadith's perspective about buying and selling and the badith about usury. This paper aims to bighlight the allowable and probibited buying and selling of credit, which departs from the traditions about buying and selling and usury. By looking at what kind of buying and selling of credit is allowed in Islam, it is hoped that it can understand the public who carry out credit buying and selling transactions. This article uses qualitative research that is the library in nature. The materials in this study were taken from library materials such as books and scientific articles published in journals related to the issues discussed, namely the implementation of the traditions of buying and selling and usury on the credit system. The data analysis techniques used were data reduction, data presentation, and conclusion drawing. The results of the analysis show that getting a profit more than the regular price in buying and selling credit is sometbing logical because buying and selling credit makes it easy for all people, mostly Muslims, when they need sometbing or goods but have not been able to buy it in cash, so that makes buying and selling on credit as an alternative way.
\end{abstract}

Keywords: Education Level, Islamic Financial Literacy, Culture, Religiosity, Interest in 
Saving.

Keywords: Hadith, buying and selling, Riba, Credit

\begin{abstract}
Abstrak
Tulisan ini membahas mengenai jual beli kredit yang berpotensi mengandung riba. Jual beli kredit tersebut ditelaah dari perspektif hadis tentang jual beli dan hadis tentang riba. Tulisan ini bertujuan menyoroti jual beli kredit yang dibolehkan dan tidak dibolehkan yang berangkat dari hadis-hadis tentang jual beli dan riba. Dengan melihat jual beli kredit seperti apa yang dibolehkan dalam Islam, maka diharapkan dapat memberikan pemahaman kepada khalayak masyarakat yang melakukan transaksi jual beli kredit. Artikel ini menggunakan penelitian kualitatif yang bersifat pustaka. Bahan-bahan dalam penelitian ini diambil dari bahan pustaka seperti buku dan artikel ilmiah yang diterbitkan di jurnal yang berkaitan dengan permasalahan yang dibahas yaitu tentang implementasi hadis-hadis jual beli dan riba pada sistem kredit. Teknik analisis data yang digunakan yaitu reduksi data, penyajian data, dan penarikan kesimpulan. Hasil analisis menunjukkan mendapatkan keuntungan lebih dari harga normal dalam jual beli kredit, merupakan sesuatu hal yang logis, karena pada jual beli kredit ini sejatinya memberikan kemudahan bagi seluruh manusia terkhusus umat Islam ketika sedang membutuhkan sesuatu benda atau barang, namun belum mampu membelinya secara tunai sehingga menempuh jual beli secara kredit sebagai jalan alternatif.
\end{abstract}

Kata kunci: Hadis, Jual beli, Riba, Kredit

\title{
1. PENDAHULUAN
}

Dalam Islam, kegiatan ekonomi merupakan satu di antara aspek yang urgen untuk mendapatkan kemuliaan hidup di dunia. Oleh karenanya, kegiatan ekonomi perlu dituntun dan dikontrol supaya sejalan tujuan syariah Islam (Batubara, 2017: 124). Etika transaksi dalam muamalah merupakan sesuatu yang tidak dapat dipisahkan dengan kegiatan ekonomi itu sendiri. Agar kepentingan semua pihak dapat terlindungi dalam setiap akad yang dilakukan maka harus ditentukan terlebih dahulu rukun dan syarat sahnya. Salah satu syarat sahnya perjanjian yang dilakukan dalam transaksi jual beli yang tidak mengandung riba (Ramly, 2017: 184). Secara luas, muamalah berarti hukum Allah yang mengatur manusia dengan segala urusannya di dunia. Namun apabila di dalam pengertian secara sempit, muamalah merupakan aturan hukum yang mengatur berkaitan dengan cara mengembangkan dan memperoleh harta benda oleh manusia yang satu dengan manusia lainnya (Hadi, 2019: 234-235). Meskipun hukum Islam merupakan hak prerogatif Allah yang menentukan segala-galanya, namun manusia di sini sebagai subjek hukum dapat melakukan ijtihad untuk menentukan hukum tersebut sesuai dengan kondisi dan situasi tertentu selama tidak keluar dari Al-Qur'an dan Hadis (Witro, 2021: 15-16)

Agama Islam menawarkan seperangkat aturan kepada manusia dalam melakukan jual beli yang meliputi rukun dan syarat jual beli, hukum jual beli, akad dalam jual beli, prinsip dasar jual beli, dan barang yang diperjualbelikan. Jual memiliki prinsip dasar yaitu saling menguntung satu sama lain, baik itu penjual maupun pembeli. Kedua-keduanya harus memiliki dan memegang prinsip dasar dari jual beli. Prinsip dasar jual beli itu adalah tolong-menolong. Penjual berusaha memenuhi kebutuhan yang diperlukan pembeli, begitu pun sebaliknya, pembeli berusaha menolong penjual dengan membeli barang dagangannya, sehingga dari proses ini terjadi sigma 
kepuasan (Apipudin, 2014: 2; Witro, 2019: 35).

Namun apabila yang terjadi sebaliknya dalam transaksi jual beli, salah satu pihak justru mengambil keuntungan dengan cara yang batil atau melakukan dua akad dalam satu proses transaksi, maka transaksi ini bisa termasuk dalam kategori riba. Hal seperti ini juga terjadi pada jual beli kredit. Kredit merupakan transaksi jual beli yang pembayarannya ditangguhkan oleh pembeli atau dilakukan secara berangsur-angsur kepada penjual sesuai dengan kesepakatan yang telah ditetapkan (Muhibbuddin, 2017: 229).

Pada praktik jual beli kredit, riba sering terjadi ketika pembeli telat membayar maka harga yang ditetapkan kemudian dengan harga yang ditetapkan di awalnya pun mengalami kenaikan. Terlibatnya unsur riba ke dalam suatu transaksi atau kesepakatan bisnis akan menyebabkan transaksi tersebut menjadi batal atau tidak sah (batil). Kontrak yang batil tidak mempunyai akibat hukum sama sekali, karena menurut hukum Islam, kontrak yang batil merupakan kontrak yang tidak pernah terjadi (Ramly, 2017: 184). Oleh karenanya, penting sekali melihat kembali setiap kontrak yang dilakukan agar sesuai dengan nash. Selain Al-Qur'an, ketentuan-ketentuan jual beli yang mengandung riba diatur dalam Hadis.

Penelitian tentang riba dan jual beli dengan sistem kredit sudah dilakukan. Busyro (2009) tentang Riba dalam Al-Qur'an dan Sunnah (Kajian Tematik. Ayat-Ayat dan Hadis Abkam). Dalam penelitian ini menunjukkan bahwa pelarangan riba disebabkan terdapat unsur zhalim yang dilakukan oleh satu pihak kepada pihak lain. Hal ini tentunya tidak dibolehkan dalam Islam. Dalam Al-Quran dijelaskan mengenai riba nasi'ah, sementara dalam hadis dijelaskan riba fadhal, dan lain sebagainya. Secara historis, praktek riba pada masyarakat Arab sudah biasa dijumpai dalam kehidupan sehari-hari. Oleh karenanya dengan praktek yang sudah mendarah daging, praktek riba ini dilarang dengan cara tadarruj (bertahap) atau berangsur-angsur, sebagaimana pelarangan khamar. Nurhadi (2019) tentang Tematik. Hadis tentang Riba dalam Kitab Shabih Bukhari. Dalam penelitian ini dijelaskan mengenai pemetaan hadis shahih tentang riba yang terdapat dalam kitab Shahih Bukhari. Berangkat dari pemetaan tersebut kemudian dijelaskan berdasarkan hadishadis yang sudah dikategorikan atau masuk dalam tema riba. Muhibbuddin (2017) tentang kredit dalam perspektif hukum Islam. Dalam kajian ini ditemukan bahwa jual beli dengan cara pembayaran ditangguhkan atau pembayaran yang dilakukan dengan cepat, maka harga akan lebih murah sudah dikenal dalam fiqih. Begitupun sebaiknya, jika penangguhan dilakukan dalam waktu yang cukup lama, maka harganya akan lebih tinggi. Lebih lanjut Muhibbuddin menjelaskan bertambahnya harga seiring dengan bertambahnya lama waktu pembayaan sebagaimana yang terjadi pada jual beli kredit merupakan hal yang wajar. Oleh karenanya di sisi lain, jual beli dengan metode seperti ini dapat membantu masyarakat yang berpenghasilan menengah kebawah karena tidak mampu melakukan pembayaraan secara tunai ketika membeli barang yang mahal.

Tulisan ini membahas mengenai jual beli kredit yang berpotensi mengandung riba. Jual beli kredit tersebut ditelaah dari perspektif hadis tentang jual beli dan hadis tentang riba. Tulisan ini bertujuan menyoroti jual beli kredit yang dibolehkan dan tidak dibolehkan yang berangkat dari hadis-hadis tentang jual beli dan riba. Dengan melihat jual beli kredit seperti apa yang dibolehkan dalam Islam, maka diharapkan dapat memberikan pemahaman kepada khalayak masyarakat yang melakukan transaksi jual beli kredit.

\section{METODE PENELITIAN}

Artikel ini menggunakan penelitian kualitatif yang bersifat pustaka. Bahan-bahan dalam penelitian ini diambil dari bahan pustaka seperti buku dan artikel ilmiah yang diterbitkan di jurnal yang berkaitan dengan permasalahan yang dibahas yaitu tentang implementasi hadis-hadis jual beli 
dan riba pada sistem kredit. Data-data dikumpulkan dengan membaca dan memahami setelah bahan-bahan yang sudah dikumpulkan. Data-data yang telah dikumpulkan disajikan dengan naratif deskriptif dan dianalisis dengan teknik analisis yaitu reduksi data, penyajian data, dan penarikan kesimpulan.(Miles \& Huberman, 1984: 21-24).

\section{HASIL PENELITIAN DAN PEMBAHASAN}

\subsection{Haill}

a) Hadis Tentang Jual Beli Riba

Sebenarnya ada banyak ada yang membahas jual beli dan riba, di sini hanya disebutkan beberapa:

Tentang larangan menjual makanan sebelum menerimanya secara sempurna

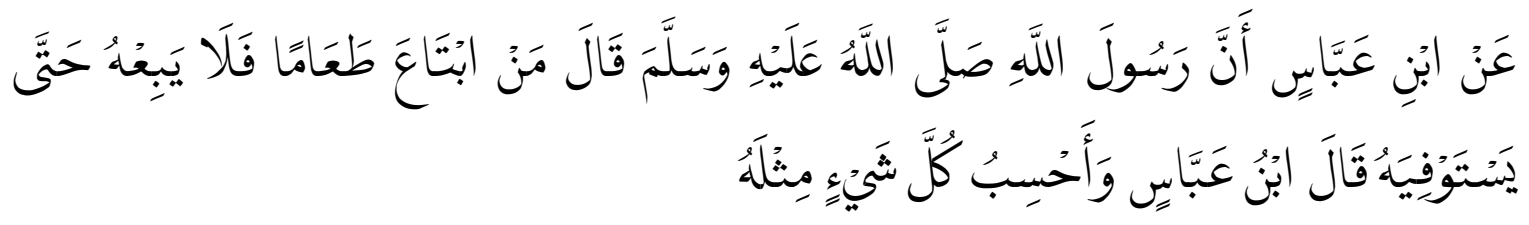

Artinya:

Dari Ibnu Abbas r.a., bahwa Rasulullah s.a.w. bersabda, "Barang siapa membeli makanan, maka janganlah menjualnya (kembali) hingga ia menerimanya (terlebih dabulu) secara sempurna" Ibnu Abbas berkata, "Saya kira semua barang sama dengan makanan" (H. R. Muslim).

\section{Jual Beli Kurma Onggokan}

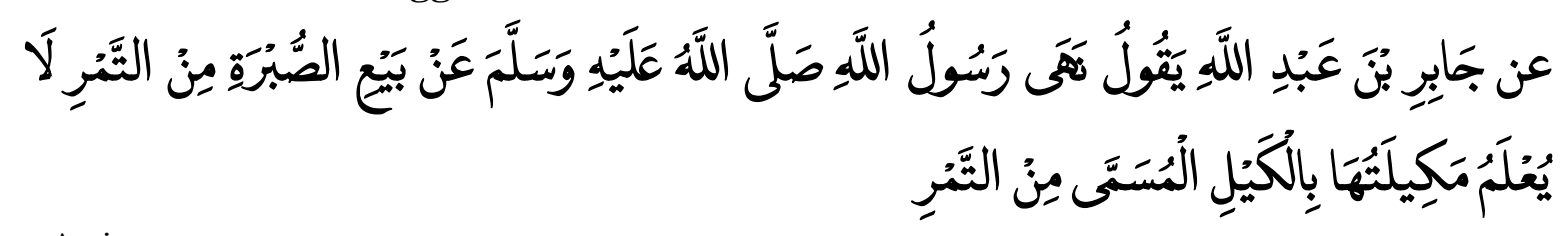

Artinya:

Dari Jabir bin Abdullah r.a., dia berkata, "Rasulullah s.a.w. melarang jual-beli kurma onggokan yang tidak diketahui takarannva dengan kurma yang jelas takarannya” (H. R. Muslim).

\section{Orang yang memberi makan riba}

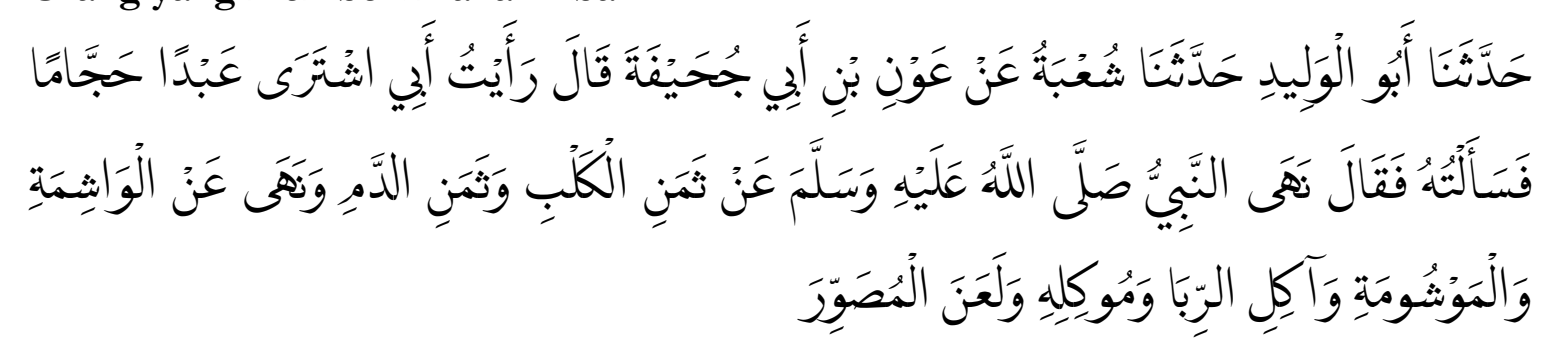


Artinya:

Telah menceritakan kepada kami Abu Al Walid telah menceritakan kepada kami Syu'bah dari 'Aun bin Abu Juhaifah berkata, aku melihat bapakku membeli seorang budak sebagai tukang bekam lalu aku tanyakan kepadanya maka dia berkata; "Nabi shallallahu 'alaibi wasallam telah melarang harga (uang hasil jual beli) anjing, darah dan melarang orang yang membuat tato dan yang minta ditato dan pemakan riba' dan yang meminjam riba serta melaknat pembuat patung” (H. R. Bukhari).

\section{Laknat bagi orang yang memakan riba dan orang yang mewakilkannya}

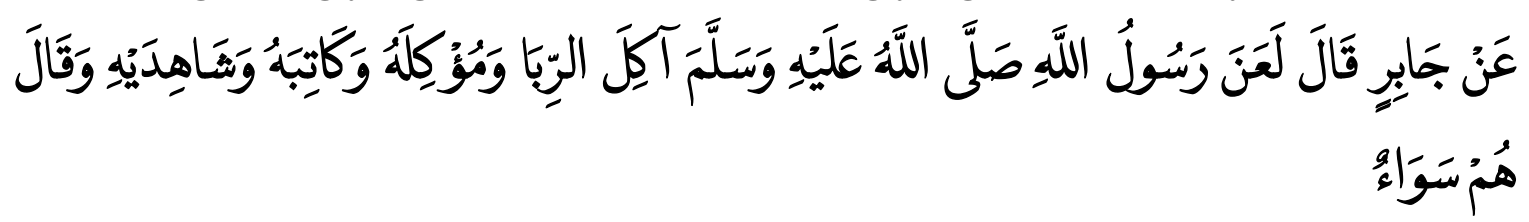

Artinya:

Dari Jabir r.a., dia berkata, "Rasulullah s.a.w. melaknat orang yang memakan hasil riba, orang yang mewakilkannya, penulisnya, dan kedua orang saksinya. Setelah itu Rasulullab juga bersabda, 'Mereka semua sama'” (H. R. Muslim).

\section{Penukaran Uang dan Jual Beli Emas dengan Perak Secara Tunai}

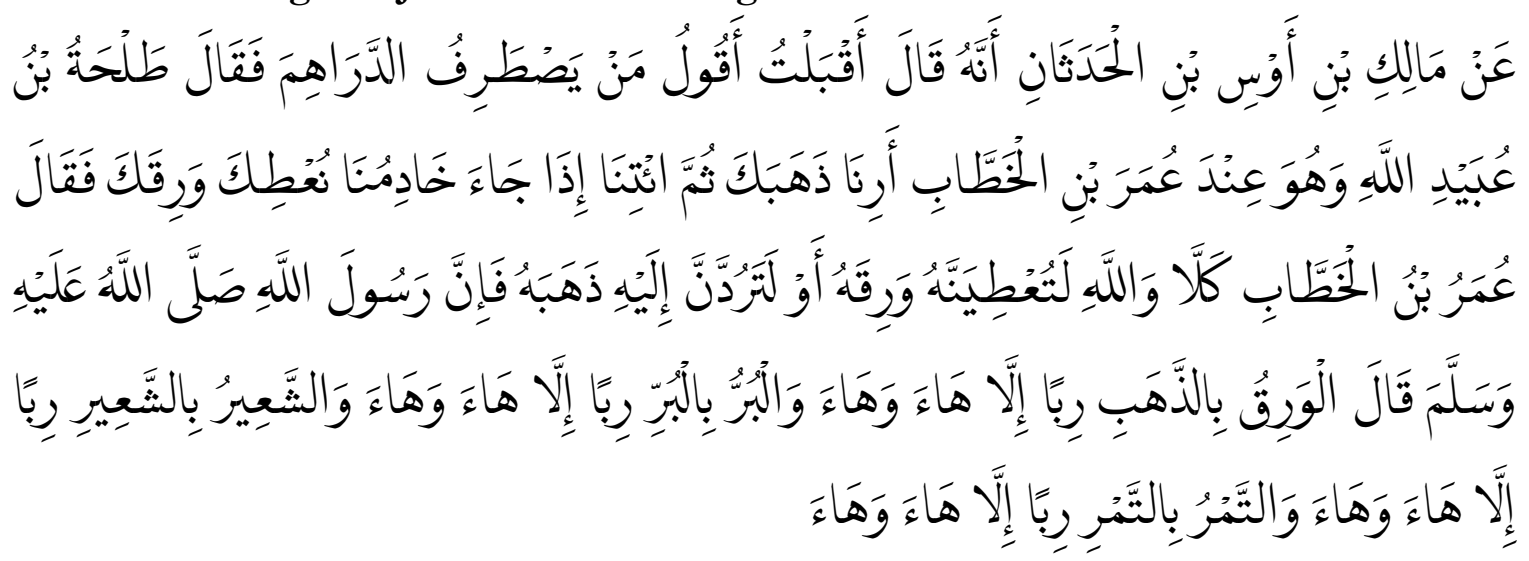

Artinya:

Dari Malik bin Aus bin Hadatsan, dia berkata. "Pada suatu hari saya pernah datang (ke suatu tempat) seraya berkata, 'Adakah di antara kalian yang ingin menukarkan dirham?' Maka, Thalhah bin

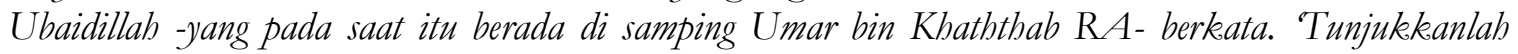
emasmu dan berikanlah kepada saya! Nanti, apabila pelayan saya datang, maka saya akan memberikan perak kepadamu'." Mendengar transaksi jual beli seperti itu, Umar bin Khaththab terperanjat dan langsung berkata, 'Demi Allah, janganlah kalian melakukan jual beli seperti itu!' Sebaiknya, kamu berikan perak tersebut sekarang atau kamu kembalikan emasnya. Bukankah Rasulullah SAW bersabda, "Perak ditukar dengan emas itu riba, kecuali jika serah terimanya pada saat itu juga. Gandum ditukar dengan gandum itu riba, kecuali jika serah terimanya pada saat itu juga. Kurma ditukar dengan kurma itu juga riba, kecuali jike serah terimanya pada saat itu juga" (H. R. Muslim). 


\section{Tinjauan Umum tentang Jual Beli}

Jual beli merupakan satu di antara aktivitas masyarakat yang selalu terjadi setiap harinya. Namun tidak semua orang mengetahui dan memahami cara atau pelaksanaan proses transaksi jual beli yang baik dan benar menurut hukum Islam. Kalau non Muslim sudah sewajarnya tidak memahami perkara ini, tetapi akan menjadi hal yang ironi, jika seseorang yang notabene Muslim yang tidak memahaminya (Shobirin, 2016: 240).

Pada dasarnya Jual beli terdiri dari dua suku kata, yakni jual dan beli. Dua kata ini seolah-olah memiliki makna yang bolak-balik dan bertolak belakang satu sama lain. Kata jual, mengindikasikan terdapat perbuatan/ proses menjual, begitu pun dengan kata beli, terdapat perbuatan/ proses membeli. Dalam pengertian lain, bila diartikan secara lengkap, jual beli berarti menukar sesuatu dengan sesuatu. Kemudian jika diartikan secara syar'i, jual beli bisa juga bermakna suatu perbuatan menukar harta dengan harta.

Jual beli merupakan sesuatu yang diridhai Allah s.w.t dan Rasulullah s.a.w. karena jual beli berbeda dengan riba. Namun ketika di dalam jual beli terdapat riba, maka jual beli tersebut tidak dibolehkan. Seluruh ulama telah sepakat bahwa riba merupakan perbuatan yang haram. Kesepakatan ini tidak hanya disepakati oleh ulama yang berasal dari agama Islam saja, namun juga oleh agamaagama samawi terdahulu yang juga tidak membolehkan praktek riba (Fitria, 2017). M. Quraish Shihab, melihat kata riba dalam segi bahasa memiliki arti "kelebihan" (Ghofur, 2016: 4). Sayid Sabiq menyatakan jual beli adalah kegiatan tukar menukar barang (harta) dengan ketentuan suka sama suka (Siswandi, 2013: 60). Imam al-Nawawi mengemukakan jual beli yaitu saling menukar harta dengan harta yang nantinya akan terjadi proses pemindahan hak milik. Hampir sama dengan apa yang disampaikan oleh Abu Qudamah, jual beli merupakan pemindahan hak milik atau pemilikan dengan cara saling menukar harta dengan harta. Sementara Hasbi ash-Shiddieqy, jual beli merupakan aktivitas terjadinya penukaran hak milik atas akad yang terdiri dari penukaran suatu harta dengan harta (Syaifullah, 2014: 373-374).

Salim mengemukakan bahwa inti dari jual beli merupakan suatu perjanjian yang dilakukan dua pihak atas barang/ benda yang bisa ditukar dan memiliki nilai secara suka sama suka. Dalam proses ini, satu pihak mendapat barang (harta), sementara pihak lain yang satunya menerima uang sebagai pembayaran dari barang yang didapatkannya tersebut. Allah sebagai dzat yang menciptakan dan mengetahui segala seluk-beluk kehidupan manusia, tentunya sudah tidak perlu menjadi perdebatan lagi, ketika perbuatan yang padanya terdapat kemaslahatan seperti jual beli, maka diperbolehkan untuk mengerjakannya. Namun sebaliknya, kepada perbuatan yang terdapat kemudharatan yang dapat menghancurkan manusia, maka akan dilarang dan tidak boleh dikerjakan (Salim, 2017: 373).

Berdasarkan uraian di atas dapat dipahami bahwa jual beli adalah aktivitas menjual dan membeli yang dilakukan oleh kedua belah pihak dengan dalih suka sama suka yang terdapat akad untuk suatu transaksi dan memberi manfaat untuk kemaslahatan bersama (Suretno, 2018: 94). Dalam transaksi jual beli, rukun dan syarat harus terpenuhi sebelum melakukan suatu transaksi. Rukun merupakan sesuatu yang wajib ada dalam setiap perbuatan muamalah. Rukun jual beli terbagi menjadi tiga macam yaitu: 1) Akad (ijab kabul) merupakan suatu ikatan yang terjadi antara pembeli dan penjual. Paling tidak ada dua syarat yaitu, pertama, tidak diselingi dengan kata lain ketika pembeli dan penjual mengucapkan akad dan kedua, jangan ada waktu yang dapat memisahkan ucapan pembeli dan penjual; 2) Pembeli dan penjual merupakan orang-orang yang berakal dan tidak mengalami gangguan kejiwaan; 3) Ma'qud alaih (objek akad). Syarat jual beli terbagi dua yaitu syarat orang yang melakukan transaksi dan syarat objek jual beli. Ada beberapa syarat dari objek jual beli: 1) Suci lagi menyucikan; 2) Memiliki manfaat menurut hukum Islam dan untuk kedua belah pihak; 3) 
Tidak disandarkan pada suatu kondisi tertentu atau disyaratkan dengan ketentuan tertentu; 4) Tidak memiliki batas waktu tertentu; 5) Bisa diserahkan; 6) Milik sendiri (penjual); 7) Bisa diindra (misalnya dilihat, disentuh, dan lain sebagainya) (Witro, Nuraeni, \& Januri, 2021: 58; Yunus, Hamdani, \& Shofia, 2018: 148-149)

\section{Tinjauan Umum tentang Riba}

Secara bahasa, riba berarti bertambah dan lebih (Harun, 2015: 44; Witro, Sar'an, \& Effendi, 2021: 90). Sedangkan menurut syara' riba merupakan akad yang tidak ada aturan menurut syara' yang terjadi dalam penukaran benda-benda tertentu. Dalam interpretasi lainnya riba merupakan suatu proses transaksi terjadinya penambahan yang diperoleh dengan transaksi atau kesepakatan yang tidak dibenarkan Al-Qur'an dan Hadis. Muh. Zuhri sebagaimana yang dikutip Fauroni, kemudian dikutip Sulaemang menyatakan akar kata riba berasal dari kata raa-ba berarti naama (tumbuh) dan ziyadah (tambahan). Riba atau dalam hal ini disebut juga dengan tambahan bisa terjadi karena faktor dari luar dan faktor dari dalam (Sulaemang L, 2015: 159).

Dalam perkembangan makna riba, dilihat dari pengertiannya yang berbentuk kelebihan atau bonus dari transaksi yang tidak mendapatkan balasan atau imbalan. Menurut Ibnu al-Arabi menyatakan bahwa kalau dilihat sejarah, masyarakat jahiliyah pada hakikatnya sudah paham dan mengetahui bahwa apa yang dilakukan seperti riba adalah sesuatu yang batil, namun mereka tetap melakukannya. Peraturan-peraturan yang ditetapkan oleh Allah dan Rasul, sebenarnya mereka cukup memahami dan mengetahui bahwa riba sebagai sesuatu yang dilarang. Namun mereka terlena atas nafsu yang membuat mereka lupa atas titah Allah tersebut. Salah satu kebiasaan masyarakat di kala itu adalah melakukan barter atau menukar benda sejenis, akan tetapi menuai unsur riba dalam artian mendapatkan untung pada satu pihak saja. Contoh menukar mangga bagus dengan mangga busuk, kurma basah dengan kurma kering, dan lain sebagainya. Peristiwa ini bisa juga terjadi pada benda yang tidak sejenis, tetapi disyaratkan adanya tambahan pada waktu yang akan datang (Busyro, 2009: $3-4)$.

Pembahasan terkait riba secara universalnya menjadi dua bagian yaitu riba jual beli dan riba utang piutang. Sedangkan pada bagian riba jual beli dibagi menjadi dua bagian yaitu riba nasi'ah dan riba fadhl, sedangkan riba utang piutang juga terbagi dua bagian yaitu riba jahiliyah dan riba qardh.

1. Riba nasiah merupakan penangguhan penerimaan atau penyerahan barang yang berunsur riba dengan barang yang berunsur riba lainnya. Riba nasi'ab ini ada karena tambahan, perubahan, atau perbedaan antara barang yang diserahkan sekarang dan barang yang akan diterima nantinya.

2. Riba fadhl merupakan pertukaran barang dengan takaran atau sejenis dengan kadar yang berbeda, sementara barang yang ditukarkan dalam akad tersebut adalah barang yang berjenis riba.

3. Riba jabiliyah merupakan tambahan yang berasal dari si peminjam tidak mampu membayar hutang dari waktu yang telah ditetapkan dan ketika membayar lebih dari pokoknya, atau yang dipinjamnya.

Riba qardh merupakan tingkat kelebihan pada suatu manfaat barang tertentu yang disyaratkan terhadap seseorang yang berutang (Parisi, Hermawan, Kurniawan, \& Habibullah, 2018: 24)

\section{Implementasi hadis-hadis jual beli dan riba pada sistem kredit}

Jual beli kredit kebanyakan digemari masyarakat dalam kegiatan ekonomi bisnis. Jual beli kredit merupakan salah satu transaksi muamalah untuk mendapatkan keuntungan dan barang dengan cepat. Islam sudah menjelaskan bahwa untuk mendapatkan keuntungan tidak dibolehkan jika terdapat riba. Apabila terdapat riba dalam pinjaman maka pinjaman tersebut haram karena di dalamnya terdapat tambahan harga dan tambahan tersebut pasti tidak akan menguntungkan kedua 
belah pihak tersebut (Nurhadi, 2019: 76). Dalam perkembangan jual beli kredit, bisa dilihat pada masa dahulu masih belum tersebar luas, akan tetapi seiring berjalannya waktu kian hari perkembangannya semakin pesat dalam menjalankan jual beli kredit.

Pembelian barang secara kredit oleh masyarakat modern semakin meningkat. Problematika yang terjadi di masyarakat yaitu kebutuhan akan barang, akan masyarakat belum memiliki uang tunai, sehingga mengambil sikap dengan cara kredit dengan tambahan harga daripada harga normal. Sebaliknya ada sebagian masyarakat yang butuh uang tunai, akan tetap tidak ada yang memberikan hutang, sehingga mengambil tambahan harga secara jual beli kredit. Terdapat tiga pendapat ulama mengenai hukum jual beli kredit dengan tambahan harga: pertama, hukumnya haram secara mutlak; kedua, hukumnya boleh dan ketiga, hukumnya di antara haram dan boleh.

Jual beli kredit menurut jumhur ulama diperbolehkan, akan tetapi harus dilihat dulu pada prakteknya yang tidak terindikasi riba. Secara komprehensif, sejatinya jual beli kredit ada yang membolehkan dan ada yang tidak membolehkan. Oleh sebab itu, maka harus diketahui terlebih dahulu di mana letak yang diperbolehkan dan di mana letak yang tidak diperbolehkan jual beli kredit.

\section{KESIMPULAN}

Mendapatkan keuntungan lebih dari harga normal dalam jual beli kredit, merupakan sesuatu hal yang logis, karena dapat dianalogikan seperti halnya tanah yang setiap tahun semakin tinggi harganya. Pada jual beli kredit ini sejatinya memberikan kemudahan bagi seluruh manusia terkhusus umat Islam ketika sedang membutuhkan sesuatu benda atau barang, namun belum mampu membelinya secara tunai sehingga menempuh jual beli secara kredit sebagai jalan alternatif. Sejatinya dalam praktek jual beli kredit ada yang memperbolehkan dan ada yang tidak memperbolehkan, bagi

yang memperbolehkan yaitu ketika dari kedua belah pihak terjadi transaksi jual beli yang saling menguntungkan dan tidak memberatkan kedua belah pihak. Sedangkan dalam perspektif yang tidak membolehkan terjadi transaksi jual beli yang di dalamnya terdapat unsur riba yaitu berupa penambahan jumlah harga dan memberatkan salah satu pihak.

\section{DAFTAR REFERESI}

Apipudin, A. (2014). KONSEP JUAL BELI dalam ISLAM (Analisis Pemikiran Abdu Al-Rahman Al-Jaziri dalam Kitab Al-Fiqh 'Ala AlMadahib Al-Arba'ah). Islaminomic, 5(2), 1-11. Retrieved from https://www.neliti.com/publications/267929/konsep-jual-beli-dalam-islam-analisispemikiran-abdu-al-rahman-al-jaziri-dalam-k\#cite

Batubara, D. (2017). Solusi Ekonomi Islam Terhadap Rekayasa Helah (Praktek Riba). AL-FALAH: Journal of Islamic Economics, 2(2), 123-138. https://doi.org/10.29240/jie.v2i2.262

Busyro. (2009). RIBA DALAM AL-QUR'AN DAN SUNNAH (Kajian tematik Ayat-ayat dan Hadis Ahkam). Al-Hurriyah, 10(1), 1-17. https://doi.org/10.30983/alhurriyah.v10i1.372

Fitria, T. N. (2017). Bisnis Jual Beli Online (Online Shop) Dalam Hukum Islam Dan Hukum Negara. Jurnal Ilmiah Ekonomi Islam, 3(1), 52-62. https://doi.org/10.29040/jiei.v3i01.99

Ghofur, A. (2016). Konsep Riba Dalam Al-Qur'an. Economica: Jurnal Ekonomi Islam, 7(1), 1-26. https://doi.org/10.21580/economica.2016.7.1.1030 
Hadi, R. (2019). Analisis Praktek Jual Beli Dropshipping dalam Perspektif Ekonomi Islam. ATTAW ASSUTH: Jurnal Ekonomi Islam, 4(2), 231-251. https://doi.org/10.30821/ajei.v4i2.5548

Harun, H. (2015). Riba Menurut Pemikiran M. Quraish Shihab (Tela'ah Illat Hukum Larangan Riba Dalam Al-Qur'an). Subuf, 27(1), 38-59. Retrieved from http://journals.ums.ac.id/index.php/suhuf/article/view/668

Miles, M. B., \& Huberman, A. M. (1984). Qualitative Data Analysis (a Source book of New Methods). Beverly Hills: Sage Publications.

Muhibbuddin, M. (2017). Credit: An Islamic Law Perspective. Al-Mizan, 13(2), 227-242. https://doi.org/10.30603/am.v13i2.912

Nurhadi, N. (2019). Tematik Hadis Tentang Riba Dalam Kitab Shahih Bukhari. Syarikat: Jurnal Rumpun Ekonomi Syariah, 2(1), 75-90. https://doi.org/10.25299/syarikat.2019.vol2(1).3726

Parisi, S. Al, Hermawan, I., Kurniawan, M., \& Habibullah, I. S. (2018). Perspektif Riba dan Studi Kontemporer-Nya dengan Pendekatan Tafsir Al Quran dan Hadits. JESI Jurnal Ekonomi Syariah Indonesia), 8(1), 23-36. https://doi.org/10.21927/jesi.2018.8(1).23-36

Ramly, A. R. (2017). Analisis Jual Beli Modern dalam Islam. Jurnal Akad, 1(1), 184-202. Retrieved from http://ojs.serambimekkah.ac.id/akad/article/view/240

Salim, M. (2017). Jual Beli Secara Online Menurut Pandangan Hukum Islam. Al Daulah: Jurnal Hukum Pidana Dan Ketatanegaraan, 6(2), 371-386. https://doi.org/10.24252/ad.v6i2.4890

Shobirin, S. (2016). Jual Beli Dalam Pandangan Islam. BISNIS : Jurnal Bisnis Dan Manajemen Islam, 3(2), 239-261. https://doi.org/10.21043/bisnis.v3i2.1494

Siswandi, S. (2013). Jual Beli dalam Perspektif Islam. Jurnal Ummul Qura, 3(2), 59-65. Retrieved from http://ejournal.kopertais4.or.id/index.php/qura/issue/view/531

Sulaemang L. (2015). Hukum Riba dalam Perspektif Hadis Jabir ra. Jurnal Al-'Adl, 8(1), 156-172. https://doi.org/10.31332/aladl.v8i1.355

Suretno, S. (2018). Jual Beli Dalam Perspektif Al-Qur'an. Ad Deenar: Jurnal Ekonomi Dan Bisnis Islam, 2(1), 93-193. https://doi.org/10.30868/ad.v2i01.240

Syaifullah, S. (2014). Etika Jual Beli Dalam Islam. HUNAFA: Jurnal Studia Islamika, 11(2), 371-388. https://doi.org/10.24239/jsi.v11i2.361.371-387

Witro, D. (2019). Praktek Jual Beli Parang dengan Cara Penumpukan untuk Meningkatkan Harga di Desa Koto Padang Perspektif Hukum Islam. Al-Qisthu: Jurnal Kajian Ilmu-Imu Hukum, 17(1), 34-40. https://doi.org/10.32694/010710

Witro, D. (2021). Nilai Wasathiyah dan Harakah dalam Hukum Ekonomi Syariah: Sebuah Pendekatan Filosofis Sikap dan Persepsi Bankir terhadap Bunga Bank. Al-Huquq: Journal of Indonesian Islamic Economic Law, 3(1), 14-33. https://doi.org/10.19105/alhuquq.v3i1.4570

Witro, D., Nuraeni, N., \& Januri, M. F. (2021). Classification of Aqad in Sharia Economic Law. Nurani, 21(1), 55-68. https://doi.org/10.19109/nurani.v21i1.8387

Witro, D., Sar'an, M., \& Effendi, D. (2021). Qaidah Furu' fi al-Riba dan Implementasinya. IQTISHADUNA, 12(1), 89-101. https://doi.org/10.20414/iqtishaduna.v12i1.3017 
Yunus, M., Hamdani, F. F. R. S., \& Shofia, G. K. (2018). Tinjauan Fikih Muamalah Terhadap Akad Jual Beli Dalam Transaksi Online Pada Aplikasi Go-Food. Amwaluna: Jurnal Ekonomi Dan Keuangan Syariah, 2(1), 135-146. https://doi.org/10.29313/amwaluna.v2i1.3363 